\title{
Nilai Moral-Lokalitas Banyumas pada Cerita Rakyat Pusaka Setan Kober
}

\author{
Mulasih \\ Universitas Peradaban Bumiayu \\ mulasih_tary@yahoo.com
}

\begin{abstract}
Abstrak
Mengkaji sastra berarti mengkaji kehidupan sosial. Hal itu bermakna, bahwa kajian tentang manusia salah satunya terdapat dalam karya sastra yaitu cerita rakyat. Jadi, bisa dikatakan dengan meneliti cerita rakyat kita bisa mengetahui segala hal dari kehidupan sosial masyarakat suatu daerah. Salah satunya mengangkat persoalan moral yang bersumber dari suatu daerah. Dalam hal ini Banyumas sebagai basis wilayah budaya, sangat menarik untuk diteliti misalnya dari pola interaksi sosialnya dan dari aspek bahasanya termasuk juga cerita rakyat yang dimilikinya. Oleh karena itu, penting untuk meneliti relasi nilai moral yang terdapat dalam cerita rakyat yang berada di Banyumas. Sehingga peneliti mengambi judul nilai Moral-Lokalitas Banyumas pada Cerita Rakyat Pusaka Setan Kober, dengan harapan mengetahui relasi antara nilai-nilai morallokal dalam cerita rakyat Banyumas dengan masyarakat Banyumas. Metode yang dipakai dalam penelitian ini adalah metode deskriptif analitik. Penelitian deskriptif analitik adalah penelitian yang bermaksud membuat gambaran mengenai situasi atau kejadian. Pengunaan metode deskripsi dalam penelitian ini bertujuan untuk memperoleh gambaran yang jelas dan tepat mengenai relasi antara nilai-nilai moral-lokal dalam cerita rakyat Banyumas dengan masyarakat Banyumas.
\end{abstract}

Kata kunci: nilai moral—lokal, Banyumas, cerita

\section{A. Pendahuluan}

Sastra merupakan salah satu seni kebahasaan yang selalu berada dalam peradaban manusia semenjak ribuan tahun yang lalu. Kehadiran sastra di tengah peradaban manusia tidak dapat ditolak, bahkan kehadiran tersebut diterima sebagai salah satu realitas sosial budaya (Mahayana, 2005: 297). Hingga saat ini sastra tidak hanya dinilai sebagai karya yang hasil imajinasi ataupun emosi, tetapi telah dianggap sebagai suatu karya kreatif yang dimanfaatkan sebagai konsumsi intelektual di samping konsumsi emosi. 
Sebagaimana yang dinyatakan Sumardjo (2004: 196) bahwa sastra lahir disebabkan desakan manusia untuk mengungkapkan dirinya, memiliki impian terhadap masalah manusia dan kemanusiaan yang berlangsung sepanjang zaman. Sastra yang telah dilahirkan oleh para sastrawan diharapkan mampu memberi kepuasan estetik dan intelek yang bermuara pada sebuah kreativitas yang tinggi dan mapan bagi pembacanya

Disadari atau tidak, sastra merupakan ekspresi jiwa manusia yang mampu memberikan rasa indah dan melahirkan rasa kagum bagi orang yang menikmatinya, tetapi sering kali karya sastra itu tidak mampu dinikmati dan dipahami sepenuhnya oleh sebagian besar masyarakat. Dalam hubungan ini perlu adanya penelaah dan peneliti sastra, dengan harapan dunia penciptaan menjadi lebih bermutu, kemampuan baca dan analisis masyarakat meningkat, disertai dengan teori ilmu kesastraan yang memadai.

Belajar ilmu sastra tidak cukup hanya memandang sastra secara utuh terhadap karya sastra itu sendiri. Sastra harus dipandang secara multidimensional dari kehidupan masyarakatnya. Di dalam sastra dapat dilihat budaya dan bahasa, etika sekaligus estetika, yang ke semuanya merupakan tata nilai yang indah dari pergulatan kehidupan sosial masyarakat. Hal itu dapat kita gali melalui pemahaman terhadap karya sastra khususnya cerita rakyat dari suatu daerah.

Menurut Joni Ariadinata (2007: 33) hal penting yang harus disadari bahwa karya sastra adalah fenomena sosial. Karya terkait dengan penulis, pembaca, dan segi kehidupan manusia yang diungkapkan dalam karya sastra. Karya sastra sebagai fenomena sosial tidak hanya terletak pada segi penciptaannya saja, tetapi juga pada hakikat karya itu sendiri. Lebih jauh lagi, dapat dikatakan reaksi sosial seorang penulis terhadap fenomena sosial yang dihadapinya mendorong ia menulis karya sastra. Oleh sebab itu, mengkaji sastra berarti mengkaji kehidupan sosial.

Hal itu bermakna, bahwa kajian tentang manusia, kehidupan, budaya, idielogi, perwatakan, bahkan menyangkut masalah-masalah lain yang lebih luas yang terkait dalam kehidupan manusia ada dalam karya sastra, salah satunya cerita rakyat. Jadi, bisa dikatakan dengan meneliti cerita rakyat kita bisa 
mengetahui segala hal dari kehidupan sosial masyarakat suatu daerah. Salah satunya mengangkat persoalan moral yang bersumber dari suatu daerah. Bagaimanapun suatu daerah pasti memiliki sistem nilai dan moralnya sendiri, dan salah satu ekspresi sistem nilai moral itu di sampaikan dengan cerita rakyat. Cerita rakyat adalah cerita yang bersumber dari nilai-nilai rakyat, oleh karena itu, cerita rakyat setiap daerah pasti menggambarkan konsep nilai moral yang berbeda.

Hal ini Banyumas sebagai basis wilayah budaya, sangat menarik untuk diteliti misalnya dari pola interaksi sosialnya dan dari aspek bahasanya termasuk juga cerita rakyat yang dimilikinya. Oleh karena itu, penting untuk meneliti relasi nilai moral yang terdapat dalam cerita rakyat yang berada di Banyumas. Peneliti akan mengambil judul "Nilai Moral-Lokalitas Banyumas pada Cerita Rakyat Pusaka Setan Kober "

Lokalitas merupakan nilai-nilai yang berupa norma-norma atau aturan yang bersumber dari budaya atau kepercayaan masyarakat sekitar (lokal) yang di jadikan pedoman hidup. Lokalitas merupakan nilai yang di junjung tinggi karena di yakini sebagai bentuk warisan dari "leluhur". Nilai lokalitas ini adalah warisan keyakinan yang secara turun-temurun dijaga, di hormati, dan dijadikan sebagai nilai untuk mengorganisir setiap perilaku masyarakat. Setiap daerah memiliki nilai lokalitas karena nilai lokalitas merupakan identitas suatu daerah yang menjadi ciri khas, seperti kebudayaan atau ilmu budaya.

Hubungan antara cerita rakyat dengan sastra sangat erat. Sastra sebagai suatu produk sosial-kultural selalu berisi nilai-nilai dan norma moral sosial kultural yang sesuai dengan pandangan pengarangnya, dan sistem nilai dan norma moral yang dipahami pengarang bersumber dari kondisi sosial budaya yang melingkupi pengarang. Oleh karena itu, cerita rakyat dalam sastra selalu mencerminkan nilainilai dan norma sosial masyarakatnya, yaitu nilai dan norma moral yang telah dipersepsi pengarang.

Hal inilah yang kemudian menyiratkan bahwa cerita rakyat merupakan "dokumen sosial" yang di dalamnya ada sistem nilai yang dilembagakan oleh penulisnya. Karena penulisnya adalah anggota masyarakat, maka sistem nilai dalam sastra dipengaruhi dan diambil dari sistem nilai yang ada di masyarakat 
sebagai tempat penulis hidup, sehingga sastra merupakan menjadi salah satu media penyampai nilai-nilai, termasuk nilai moral.

\section{B. Metode Penelitian}

Metode yang digunakan dalam menganalisis cerita rakyat di Banyumas adalah metode deskriptif analitik. Penelitian deskriptif bertujuan untuk mendeskripsikan apa-apa yang saat ini berlaku yang di dalamnya terdapat upaya mendeskripsikan, mencatat, menganalisis dan menginterprestasikan kondisi yang terjadi. Metode deskriptif analitik dilakukan dengan cara mendeskripsikan faktafakta yang kemudian disusul dengan analisis (Mardalis, 2008:26). Sumber data adalah buku cerita rakyat Banyumas. Sedangkan objeknya adalah nilai morallokal pada cerita rakyat di Banyumas.

\section{Hasil dan Pembahasan}

\section{Nilai Moral-Lokalitas dalam Cerita Pusaka Setan Kober}

Dalam cerita Pusaka Setan Kober terdapat beberapa nilai moral yaitu :

\section{a. Kejujuran}

Jujur merupakan sikap mental yang lurus hati dan terpercya, sehingga akan diharagai oleh setiap orang. Kejujuran yang diidentifikasi dalam cerpen "Pusaka Setan Kober" merupakan hal yang dijunjung tinggi oleh tokohtokohnya. Sikap jujur ini meliputi benar hati, benar perkataan, dan benar perbuatan. Benar dalam hati jika dan bersih dari segala penyakit hati seperti bohong, khianat, dan fitnah. Benar dalam perkataan jika segala ucapan seseorang adalah kebenaran bukan kebatilan dan benar dalam perbuatan.

Cerpen "Pusaka Setan Kober" secara tidak langsung menyampaikan amanat atau pesan moral mengenai penanaman sifat jujur kepada pembaca melalui gambaran dan tingkah laku para tokoh di dalamnya. Pengarang melukiskan apa yang harus ditafsirkan oleh pembaca, pemahaman dan penafsiran ini harus dilakukan berdasarkan cerita, sikap dan tingkah laku para tokohnya.

Gambaran sifat jujur terlihat ketika Kiai Kendalgrowong didatangi oleh Raden Kaligenteng yang menanyakan tentang Keris Setan Kobar yang 
dirawat oleh Kiai Kendalgrowong, Kiai Kendalgrowong jujur bahwa dia memang ditugasi untuk merawat keris setan kobar. Tetapi keris tersebut sudah dikembalikan kepada pemiliknya yaitu Bupati Sokaraja Jebungkusuma. Akan tetapi Raden Kaliganteng ngeyel dan tidak percaya dengan apa yang dikatakan oleh Kiai Kendalgrowong. Berikut kutipannya

"Pak Kiai, serahkan pusaka setan kober kepadaku," kata Raden Kaligenteng.

Kiai Kendalgrowong terkejut dan menampakkan ketidaksenangannya teradap Kaliganteng yang dianggapnya kurang sopan.

"Anak itu siapa?" tanya Kiai Kendalgrowong.

"Aku anak Bupati Kertabangsa. Bupati Jebungkusuma itu paman saya.

"Lalu apa maksudmu?"

"Sudah, jangan banyak Tanya. Serahkan segera keris itu!"

"Saya memang perawat keris itu, tetapi saya sudah menyerahkannya kepada beliau,"

"Bohong! Cepat serahkan keris itu!"

"Sungguh nak, untuk apa saya harus berbohong,"

Kutipan tersebut menggambarkan kejujuran Kiai Kendalgrowong, meskipun Raden Kaliganteng datang dengan tidak sopan ke padepokannya, tetapi Kiai Kendalgrowong menerimanya dan meladeni raden Kaliganteng. Di dalam hal ini dapat dilihat kejujuran lokalitas yang tidak didasari rasionalitas, maksudnya saat Raden Kaligenteng menanyakan pusaka setan kober, Kiai Kendalgrowong hanya mengatakan sudah mengembalikan keris tersebut, tanpa memberi penjelasan yang berbelit-belit meskipun Raden Kaligenteng tidak percaya tetapi Kiai Kendalgrowong seperti tidak perduli (ora urusan sing penting wis ngomong, percaya ngonoh ora percaya ya ngonoh).

\section{b. Berbakti Kepada Orang Tua}

Berbakti kepada orang tua melakukan perbuatan atau perkataan dengan sengaja agar orang tua bahagia. Seorang anak yang berbakti kepada orang tua, berarti dia menyadari akan jasa yang telah diberikan orangtua tanpa balasan apapun dari anak. 
Kepahlawanan dalam cerpen Pusaka setan kober ini Terlihat penanaman sifat berbakti kepada orang tua ketika Raden Kuncung bertemu dengan ayahnya yaitu Bupati Jebungkusuma ditepian sungai. Saat itu Bupati Jebungkusuma sedang bertapa untuk mencari keberadaan Raden Kaligenteng yang melarikan diri dengan menceburkan diri ke sungai. Kemudian Bupati Jebungkusuma menceritakan apa yang terjadi pada dirinya, dan Raden Kuncung akhirnya memutuskan untuk membantu ayahnya mencari Raden Kaligenteng. berikut kutipanya:

"Siapakah pemuda tampan itu?"tanya Bupati Jebungkusuma.

"Bukankah dia Raden Kuncung, Putra Bupati Sendiri," jawab pembantu pemuda itu.

"Raden Kuncung?"

Bupati Jebungkusuma mulai sadar.

"kalau begitu dia adalah anakku sendiri,"

Raden kuncung dan Bupati Jebungkusuma berpelukan, setelah itu. Bupati Jebungkusuma menceritakan peristiwa yang telah terjadi di padepokan Kiai Kendalgrowong kepada Raden Kuncung.

Mendengar peristiwa itu Raden Kuncung ingin menangkap Raden Kali genteng. Raden Kuncung menyamar menjadi dalang jemblung.

Terlihat di dalam kutipan tersebut bahwa anak yang baik adalah anak yang selalu membantu orangtuanya disaat mereka membutuhkan. Dalam cerita ini Raden Kuncung telah memberi gambaran kebaktiannya kepada orangtuanya. Nilai moral lokalitasnya ketika seorang ayah menceritakan apa yang dialaminya kepada anaknya, pasti anak tersebut akan segera bertindak, apalagi kejadian tersebut telah membuat orangtuanya marah, seorang anak pasti tidak terima dengan perlakuan orang lain terhadap orangtuanya. Meskipun orangtuanya belum tentu benar atau salah.

\section{c. Balas Budi}

Balas budi dalam cerpen pusaka setan kober ini sangat jelas tergambar, terdapat pada kutipan :

Pada suatu hari, Bupati Jebungkusuma mempertanyakan perawatan kerisnya kepada Kiai Kendalgrowong, perawat pusaka setan kober, seketika itu Kiai Kendalgrowong, perawat pusaka setan 
kober, menyerahkan keris itu kepada Bupati Jebungkusuma. Penyerahan keris seta kober dilakukan dengan upacara adat . seusai penyerahan keris. Bupati jebungkusumo memberikan hadiah kepada Kiai Kendalgrowong sebagai ucapan terimakasih, setelah itu Kiai Kendalgrowong pulang ke padepokan.

Pada kutipan tersebut jelas tergambar. Bahwa Bupati Jebungkusumo memberikan hadiah kepada Kiai Kendalgrowong karena telah merawat kerisnya dengan baik. Di sini tergambar jika seseorang telah melakukan hal yang baik dengan kita maka kita harus membalasnya dengan baik juga. Seperti kata orang banyumas ( nek kowe apik aku luwih apik).

\section{Relasi Nilai Moral-Lokal Cerita Rakyat Pusaka Setan Kober dengan}

\section{Masyarakat Banyumas.}

Masyarakat banyumas terkenal dengan legeyan yang dibentuk oleh lingkungan masyarakat yang terkenal dengan pameo adoh ratu cedak watu (jauh dari raja dekat dengan batu/gunung, sungai) sehingga tatakrama dan adat istiadat yang tercermin pada masyarakat banyumas tersebut menunjukkan tatakrama orang pedesaan.

Sehingga watak atau karakter orang banyumas disimbolkan seperti Bawor. Bawor alias carob adalah nama salah satu tokoh punakawan dalam wayang purwa. Penampilan dan bentuk bagian tubuhnya menjadi ciri legeyan (pola tingkahnya) yang menggambarkan watak (sifat kejiwaan) Bawor sebagai berikut :

a. Sabar lan nrima (sabar dan menerima apa adanya dalam kehidupan kesehariannya)

b. Berjiwa kesatria (jujur, berkepribadian baik, toleran) rukun, suka membantu orang lain dan mementingkan kepentingan bersama.

c. Cancudan (rajin dan cekatan)

d. Cablaka (lahir batinnya terbuka terhadap pertimbangan yang matang dari apa yang diucapkannya spontan dengan bahasa yang lugas tanpa basa basi). 
Dari keempat karakter tersebut mencerminkan watak masyarakat banyumas pada umumnya. Jika dihubungkan dengan cerita rakyat Pusaka Setan Kober, jelas terlihat relasinya. Dalam cerita tersebut mencerminkan sifat-sifat yang dimiliki oleh orang banyumas pada umumnya.

a. Misalkan saja pada kejujuran, orang banyumas dalam berbicara selalu blak-blakan, dan cowag (berbicara lepas dengan nada lugas). Dalam cerpen ini jelas terlihat karakter orang banyumas pada diri Kiai Kendalgrowong yang apabila berbicara blak-blakan, tanpa menyembunyikan apapun. Juga pada Raden Kaligenteng yang terangterangan meminta pusaka setan kober kepada Kiai Kendalgrowong. Dan terlihat saat Kiai Kendalgrowong mengatakan pusaka setan kober sudah Ia kembalikan ke pemiliknya, Ia tidak menjelaskan apapun lagi padahal Raden Kaligenteng tidak percaya dengan perkatan Kiai Kendalgrowong. Di sini jelas terlihat kejujuran orang banyumas memang seperti itu. Jika berbicara apa adanya tidak mementingkan rasionalitas tidak perduli lawan bicara mau percaya atau tidak, yang terpenting sudah jujur tanpa harus berbelit belit (istilahnya orang banyumas arep percaya ngonoh ora percaya ya ngonoh sing penting aku wis ngomong).

b. Lalu pada kebaktian kepada orangtua terlihat ketika Raden Kuncung bertemu dengan ayahnya yaitu Bupati Jebungkusuma ditepian sungai. Saat itu Bupati Jebungkusuma sedang bertapa untuk mencari keberadaan Raden Kaligenteng yang melarikan diri dengan menceburkan diri ke sungai. Kemudian Bupati Jebungkusuma menceritakan apa yang terjadi pada dirinya, dan Raden Kuncung akhirnya memutuskan untuk membantu ayahnya mencari Raden Kaligenteng. Dan memberikan pelajaran kepada raden kaligenteng.

Di sini terlihat kebaktian Raden Kuncung terhadap ayahnya. Meskipun dia hanya mendapat sedikit cerita tentang Raden Kaligenteng dari ayahnya. Tetapi Ia tidak terima jika orangtuanya tersebut diganggu oleh Raden Kaligenteng. Raden Kuncung langsung memutuskan membantu ayahnya untuk mengejar Kaligenteng, 
seperti itulah karakteristik orang Banyumas, ketika orang yang disayangi mendapatkan masalah mereka akan cepat bertindak. Bahkan mempertaruhkan nyawanya sekalipun dia belum tahu betul masalahnya.

c. Pada bentuk moral balas budi yaitu saat Kiai Kendalgrowong menyerahkan keris kepada Bupati Jebungkusuma. Pada acara penyerahan keris tersebut diadakan upacara adat. Kemudian Bupati Jebungkusuma menyerahkan hadiah kepada Kiai Kendalgrowong karena telah merawat pusaka setan kober dengan baik.

Dari hal tersebut bisa dilihat watak orang Banyumas, ketika ada seseorang berbuat baik maka mereka akan berbuat baik pula dengan orang tersebut istilahnya dalam bahasa Banyumas ( nek kowe apik aku luwih apik).

\section{Simpulan}

Simpulan aspek nilai Moral-Lokalitas Banyumas pada Cerita Rakyat Pusaka Setan Kober menggambarkan relasi antara cerita rakyat Banyumas dengan kehidupan orang Banyumas secara rill. Watak yang ada di dalam cerita rakyat Banyumas, mencerminkan watak orang Banyumas, yang digambarkan seperti Bawor yang memiliki watak ksatria, cacundan, dan cablaka.

\section{E. Daftar Pustaka}

Aminuddin, 2009. Pengantar Apresiasi Karya Sastra. Bandung: Sinar Baru Algensindo.

Herusatoto, Budiono.2008. Banyumas. Yogyakarta : LKIS

Nurgiyantoro, Burhan. 2007. Teori Pengkajian fiksi. Yogyakarta. Gadjah Mada University Press

Jaruki,Muhammad. 2003. Cerita Rakyat Dari Banyumas. Jakarta : PT Grasindo.

Kurniawan, Heru. 2009. Sastra Anak dalam Kajian Strukturalisme, Sosiologi, Semiotika, hingga Penulisan Kreatif. Yoyakarta: Graha Ilmu.

Mahayana, S. Maman. 2005. 9 Jawaban Sastra Indonesia. Jakarta Timur: Bening Publhishing..

Muryanto, A. Kristiawan, 2008. Aku Pandai Menulis Cerpen. Yogyakarta: PT. Citra Aji Parma.

Supriadi, Dr. Dedi. 1997. Kreativitas, Kebudayaan, dan Perkembangan Iptek. Bandung: CV. Alfabeta

Ratna, Prof. Dr. Nyoman Kutha. 2009. Teori, Metode, dan Teknik Penelitian 
Lingua Rima: Jurnal Pendidikan Program Studi Bahasa dan Sastra Indonesia Vol.6 No.2 Juli 2017

Sastra. Yogyakarta: Pustaka Pelajar. 